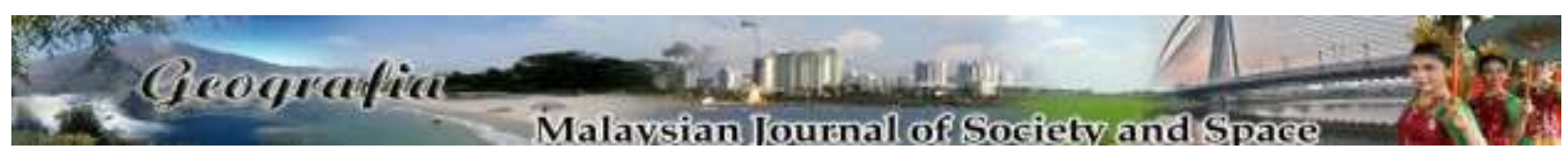

\title{
Assessment of the impact of a twin industrial area on the air quality in Bandar Baru Bangi, Selangor
}

\author{
Mastura Mahmud, Muhammad Hafiz \\ Geography Programme, Faculty of Social Sciences and Humanities \\ Universiti Kebangsaan Malaysia \\ Correspondence: Mastura Mahmud (email: mastura@ukm.edu.my)
}

Received: 23 January 2020; Accepted: 01 July 2020; Published: 28 August 2020

\begin{abstract}
The rapid industrial development in an equatorial developing country poses a dilemma where sustainable and human development should be dynamically balanced in an otherwise interdependent ecosystem. The impact of the presence of two industrial designated areas on the air quality of the surrounding residents in a satellite town of Bandar Baru Bangi (BBB), in the state of Selangor in Peninsular Malaysia was investigated by selecting four air quality sampling stations at the Selaman Industrial Park (SIP), the Bangi Industrial Estate (BIE) and two nearby $\mathrm{BBB}$ residential areas. Air quality samplings for particulates of aerodynamic diameter of 10 microns $\left(\mathrm{PM}_{10}\right)$ and gases such as carbon monoxide $(\mathrm{CO})$ and nitrogen dioxide $\left(\mathrm{NO}_{2}\right)$ were conducted. ANOVA analysis showed that the concentrations between the four stations were different, where higher daily average concentrations for all air parameters exist at the BIE. The $\mathrm{PM}_{10}$ and $\mathrm{CO}$ concentrations were below the New Malaysia Ambient Air Quality Standard (2020) (NMAAQS) unlike the $\mathrm{NO}_{2}$ concentrations at both the industrial parks that exceeded the NMAAQS (2020) of $0.15 \mathrm{ppm}$. The HYSPLIT modelled air trajectory analysis indicated that weak wind velocities during the southwest monsoon over Malaysia dispersed the pollutants from the industrial areas. The predicted dispersion from the HYSPLIT model simulated different plume patterns for the five days from the two industrial areas due to different wind regime of the day during the southwest monsoon. The results emphasize the importance of good proper urban planning particularly for the placement of industrial areas within a township.
\end{abstract}

Keywords: air quality, equatorial, light industry, monsoon, residential, twin industrial area

\section{Introduction}

Malaysia is a country in Southeast Asia that is diversifying its economy through the development of its industrial sector. Land cover changes due to urbanization in Asia (Ghosh et al., 2018) with commercial and industrial growth from the rapid development policy has led to the 
environmental issues such as air pollution and environmental degradation harmful to the surrounding public if the criteria limits set by the authorities to protect the health of the public are exceeded. Effluents such as dust and toxic gases from the medium and heavy stationary industrial sources can be detrimental to human health especially in designated industrial estates (Pinyochatchinda \& Walsh, 2014). Industrial estates are usually situated near transport infrastructure such as highways and are sources of polluting gaseous emissions, including greenhouse gases and dust that affect the local air quality (Gorham, 2002) as well as noise pollution. According to the Department of Environment (DOE), nearly 82 percent of the three million tons of air pollutants in Malaysia were emitted by motor vehicles (DOE, 2012). As for the rest, nearly 9 percent of air pollutants were contributed by power stations and 5 percent was liberated by the industrial sector (DOE, 2012). The three main sources of air pollution in Malaysia are mobile sources, stationary sources (factories and power plants), waste combustion and the seasonal transboundary atmospheric pollution caused by forest fires in Indonesia that have resulted in severe haze episodes in 1991, 1992, 1994, 1997 (Mahmud, 2009a), 2004 (Mahmud, 2013), 2005 (Mahmud, 2009b), 2015 (Eck et al., 2019).

Clusters of industries which are housed at industrial estates provide employment opportunities and market competitiveness (Sonobe \& Keijiro, 2006). Physical factors such as accessibility, power, topography, and socio-economic factors such as communication, government policy, labour supply influence the industrial placement. The concentration of multiple activities, whether heavy, medium or light industries, in addition to the road traffic (Paraschiva \& Paraschiva, 2019) will emit air pollution to the atmosphere that can be detrimental to the health of the surrounding human inhabitants.

The objective of this study is to investigate the air quality at the satellite town of BBB, with sampling points located near two industrial facilities and their nearby residential areas. Grab samples of air parameters are collected at each location. An air dispersion model, Hysplit4, will also be performed to estimate the downwind pathway and the dispersion of the air pollutants from the two industrial sites. The results will reflect the ambient air values at the time of sampling measured in-situ, on-site by analysis of grab sampling and predicted air quality concentrations under normal atmospheric conditions using the HYSPLIT model

\section{Study area and method}

The Industrial Production Index (IPI) that measures the changes in the industrial activities such as the manufacturing, electricity, and mining sectors has increased by $4.2 \%$ December 2010 compared to December 2009 (Department of Statistics Malaysia, 2013). In order to gauge the extent of the influence of industrial activities on the air quality and quality of life to the nearby residents in Malaysia, a case study on its air quality was selected at an upcoming town of Bandar Baru Bangi, Selangor, a state on the western coast of Peninsular Malaysia (Figure 1). Bandar Baru Bangi (BBB) is a satellite town that covers an area of 2925 hectares with approximately 11,000 residential units and a population of approximately 60,000 with services that include business, light industrial, commercial, recreation, and education (Mohd Dlan \& Kassim, 2012).

There are two main light industrial areas located in BBB, one is the Selaman Industrial Park (SIP), and the other is the Bangi Industrial Estate (BIE) that is approximately $3 \mathrm{~km}$ from each other (Figure 1). They were designated as industrial zones by the local authorities due to the low land premiums and are located close to the residential areas. The industrial areas consist of small 
and medium enterprises with many large and small-sized factories. The SIP consists of 267 factory units, whilst the BIE initially consisted of 43 factory units. SIP is located in Section 10 of $\mathrm{BBB}$, Selangor and the project was completed in three phases where Phase I was fully completed in 1996 while Phase 2 and Phase 3 were completed in 1998. The light industry park consists of many plants that manufacture electrical and electronics goods, and industrial processing of primary industry of finished or semi-finished goods.

The two industrial areas are located nearby the residential areas and the distance between the perimeter of the factory and the residential areas in Section 9 are about $70 \mathrm{~m}$ to $80 \mathrm{~m}$ (Figures $2 \mathrm{a}$ and $2 \mathrm{~b}$ ). This still complies with the environmental requirements stipulated by the Department of Environment (2007) where the siting and zoning of light industries requires a buffer zone of $50 \mathrm{~m}$. The close proximity of BBB to the PLUS North-South Expressway of approximately a kilometre facilitate the transportation of goods in addition to the local traffic enhanced the air pollution especially during weekdays.

Air samples at four different stations selected were the Selaman Industrial Park (SIP) $\left(2^{\circ} 58.296{ }^{\prime} \mathrm{N} 101^{\circ} 44.774 ' \mathrm{E}\right)$, the Bangi Industrial Estate (BIE) $\left(2^{\circ} 56.803^{\prime} \mathrm{N} 101^{\circ} 45.352^{\prime} \mathrm{E}\right)$, sandwiched between a residential area in Section 9 of Bandar Baru Bangi (S9) $\left(2^{\circ} 57.619\right.$ 'N $\left.101^{\circ} 45.002^{\prime} \mathrm{E}\right)$, and another residential area at the Cempaka Apartments (CA) $\left(2^{\circ} 57.458^{\prime} \mathrm{N}\right.$ $\left.101^{\circ} 45.121^{\prime} \mathrm{E}\right)$. These residential areas consist of linked townhouses and apartments.

The field survey was carried consecutively for three working days from June 1, 2011 until June 3, 2011 from 7.00 am until 7.00 pm, and on Saturday and Sunday on 5 and 6 June 2011. Four air parameters measured were particulate matter of aerodynamic diameter of 10 micrometers or less $\left(\mathrm{PM}_{10}\right)$ and gases such as nitrogen dioxide $\left(\mathrm{NO}_{2}\right)$, and carbon dioxide $(\mathrm{CO})$. Readings were taken at hourly intervals at the four stations by using the grab method. A grab sample is a sample acquired individually which is represented as a snapshot of the current environmental condition. The $\mathrm{PM}_{10}$ concentration was measured by the Portable Aerosol Spectrometer Model 110, which is manufactured by Grimm Aerosol Technik \& Co from Germany. Concentrations of gases such as $\mathrm{CO}$ and $\mathrm{NO}_{2}$ are measured with a $V-R A E$ Multigas Monitor. The equipment is manufactured by the Honeywell RAE Systems with its Headquarters located in Sunnyvale, California, USA. Sampling for all air parameters were taken at the height of a human receptor, approximately 1 meter from the ground.

Mean daily air quality parameters were also obtained from ten air quality monitoring stations within the states of Selangor, Negeri Sembilan and Perak. These stations were monitored by the Department of Environment and provide a comparison between the level of air quality of BBB and the rest of the western coast of Peninsular Malaysia. Wind data was obtained from the Malaysian Meteorological Department to investigate on the meteorological windfield conditions on the days investigated. Forward air trajectory and dispersion analyses of the air particles that pass from Bangi was also included to investigate the direction of the pathway of the polluted air from Bangi. The Hysplit4 (Hybrid Single particle Lagrangian Integrated Trajectory) model that computed air trajectories and dispersion of pollutants based on the dispersion rate of vertical diffusivity, wind shear and horizontal deformation of the wind field (Draxler et al., 2013; Rolph et al., 2017). The meteorological data for the simulation is the Global Data Assimilation System (GDAS) at 0600 UTC. The output of the model is mainly for the analysis time at 12 hour forecasts. The dispersion model was run with meteorological data as the trajectory model for durations up to 24 hour forward (Rolph et al., 2017). The default top of the model height was 10 $\mathrm{km}$. 
A small survey was conducted to gauge the perception of the residents who reside within the vicinity of the industrial areas. They were questioned on their knowledge and awareness on the air quality within their environmental surroundings.

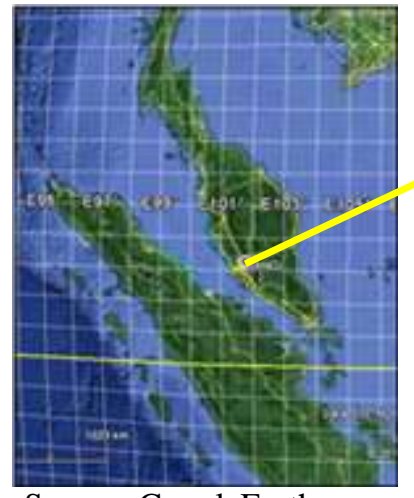

Source: GoogleEarth

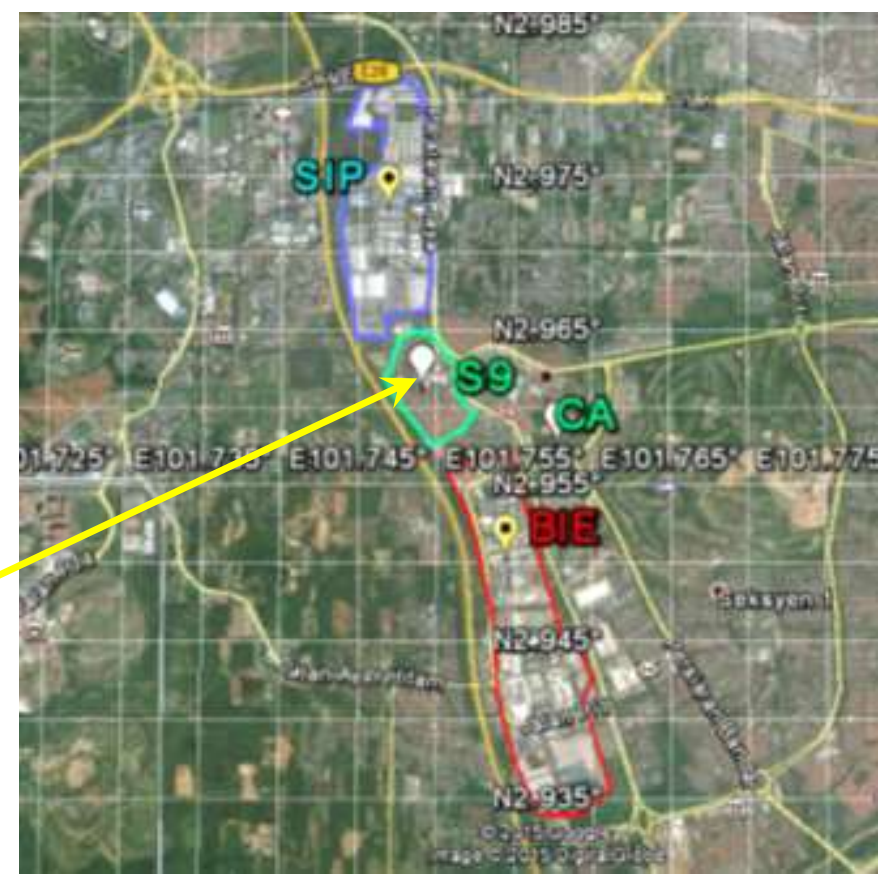

Figure 1 (a) Location of Malaysia and (b) the locations of the sampling points in Bangi (BIE, SIP, S9 and CA).

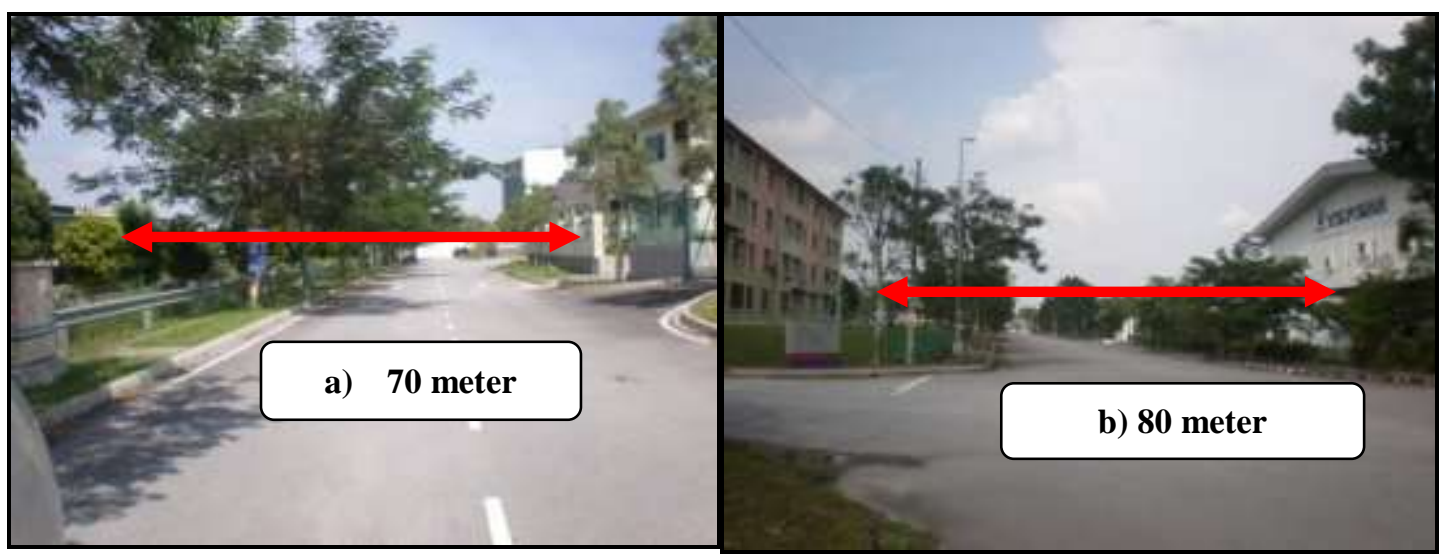

Figure 2 (a) The distance of about 70m between factory and residential area at Bangi Industrial Estate (BIE), and (b) the distance of $80 \mathrm{~m}$ between the fence of the factory and the residential area in the Selaman Industrial Park (SIP).

\section{Results and discussion}

The hourly readings of the $\mathrm{PM}_{10}$ displayed variable fluctuations during the five days of sampling. On June 1, BIE recorded peaks of $32.4 \mu \mathrm{g} / \mathrm{m}^{3}$ at $8.00 \mathrm{am}$ and $31.3 \mu \mathrm{g} / \mathrm{m}^{3}$ at $7.00 \mathrm{pm}$ (Figure 3a). 
Meanwhile, other stations displayed lower concentrations with fluctuations and higher values that were generally recorded in the mornings. $\mathrm{PM}_{10}$ values at SIP remained relatively low, beneath $15 \mu \mathrm{g} / \mathrm{m}^{3}$ for a period of 12 hours.

The $\mathrm{PM}_{10}$ concentration at BIE persistently presented higher readings than other stations during the following four days with a peak of $31.3 \mu \mathrm{g} / \mathrm{m}^{3}$ on the second day and $26.8 \mu \mathrm{g} / \mathrm{m}^{3}$ on the third day while lower readings were recorded at other sampling stations. It is evident that industrial activities at BIE and its proximity to nearby major roads increased the amount of suspended particulates compared to other stations, as shown by the lower values displayed during the weekend indicating the influence of human activities from transportation also contributed to the air quality in the surrounding areas. Lower readings were recorded within the housing areas at S9 and CA which was lined with some plants that act as a buffer. A peak value of $15.4 \mu \mathrm{g} / \mathrm{m}^{3}$ was recorded on Day 4 on Saturday at $3.00 \mathrm{pm}$ during the five days (Figure $3 \mathrm{~b}$ ). All sampling stations recorded maximum hourly $\mathrm{PM}_{10}$ concentrations (when converted to the averaging time period of 24 hours using the equation from Duffee et al., (1991) results in 40 percent lower than the hourly data) were lower than either the RMAQG criteria of $150 \mu \mathrm{g} / \mathrm{m}^{3}$ that is valid for 2011, the New Malaysia Ambient Air Quality Standard (2020) criteria of 100 $\mu \mathrm{g} / \mathrm{m}^{3}$ or the criteria level of $50 \mu \mathrm{g} / \mathrm{m}^{3}$ for an averaging period of 24 hours set by WHO Air Quality Guidelines (WHOAQG). This indicated that the air quality in terms of suspended particulate was still satisfactory at both the residential and industrial areas in BBB.

The peaks in $\mathrm{CO}$ concentrations occurred in the mornings when employees commute to work, while the afternoon and evening peaks coincided with the lunchtime activity and when some firm's operations ceased and employees returning from work. The $\mathrm{CO}$ released from transportation also played a role in the increase of CO during the peak hours. Expectedly, the concentrations of $\mathrm{CO}$ were lower during the weekend than during the weekday, especially from $7.00 \mathrm{am}$ to $9.00 \mathrm{am}$. This was due to the changing plant operating hours and reduced number of vehicles at peak times. All sampling stations recorded concentrations of $\mathrm{CO}$ that were below the criteria value of $30 \mathrm{ppm}$ within the averaging 1 hour set by the DOE.

The levels of $\mathrm{SO}_{2}$ were not detectable at both the residential housing areas at $\mathrm{S} 9$ and CA (Figure 3c). $\mathrm{SO}_{2}$ were recorded at the SIP and BIE industrial areas. As with the previous gases, $\mathrm{BIE}$ still recorded higher concentrations compared to other stations. The BIE displayed higher $\mathrm{SO}_{2}$ concentrations that ranged from $0.7 \mathrm{ppm}$ to $0.1 \mathrm{ppm}$, with higher readings detected during workdays than the weekend. These readings were above permitted RMAQG level of $0.13 \mathrm{ppm}$ for an averaging time of 1 hour on weekdays and weekends for $90 \%$ of the sampling, while only $7 \%$ exceedance occurred above the criteria levels at SIP.

The $\mathrm{NO}_{2}$ concentrations at $\mathrm{BIE}$ were on average higher than at the other stations with a minimum recorded at $0.17 \mathrm{ppm}$ and a maximum of $0.52 \mathrm{ppm}$ at $1 \mathrm{pm}$ LST on 1 June (Figure $3 \mathrm{~d}$ ). The $\mathrm{NO}_{2}$ fluctuations at BIE peaked at $0.47 \mathrm{ppm}$ at 8:00 am while a minimum of $0.10 \mathrm{ppm}$ was recorded at the $\mathrm{S} 9$ residential area at 11:00 am and at 4:00 pm at SIP. The $\mathrm{NO}_{2}$ values at the residential areas exceeded the criteria limit set by the DOE of $0.17 \mathrm{ppm}$ within an averaging time of 1 hour or the New Malaysia Ambient Air Quality Standard (2020) of $0.15 \mathrm{ppm}$ during the weekdays but not the weekends. Lower readings that ranged from $0.16 \mathrm{ppm}$ to $0.10 \mathrm{ppm}$ were recorded on Saturday and Sunday at S9 and CA. The reduction in the ambient readings was related to the industrial and human activities, as explained previously. Daily average concentrations of $\mathrm{NO}_{2}$ at the four sampling stations exceeded the New Malaysia Ambient Air Quality Standard (2020) of 0.15 ppm for an averaging period of 1 hour. The presence of $\mathrm{NO}_{2}$ gas 
was emitted from vehicles and industrial activities as well as the contribution within the surrounding housing areas during sampling.

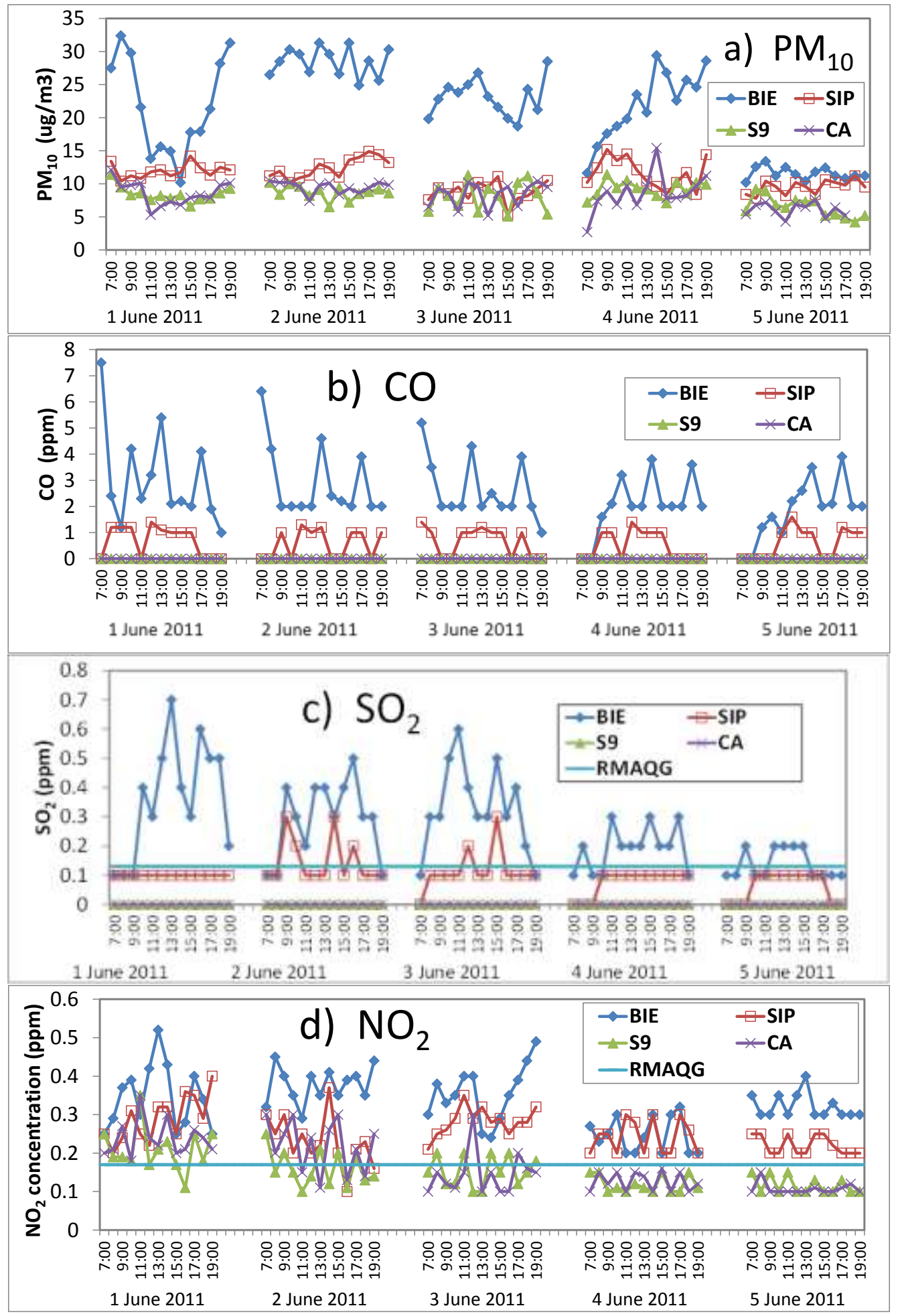

Figure 3 Concentrations of (a) $\mathrm{PM}_{10}$, (b) $\mathrm{CO}$, and (c) $\mathrm{SO}_{2}$ and (d) $\mathrm{NO}_{2}$ at the four sampling stations in $\mathrm{BBB}$ 
Descriptive statistics performed on the various air pollutants showed that the average $\mathrm{PM}_{10}$ concentration of $21.34 \mu \mathrm{g} / \mathrm{m}^{3}$ at BIE and $10.1 \mu \mathrm{g} / \mathrm{m}^{3}$ at SIP were higher than the mean concentrations of $8.1 \mu \mathrm{g} / \mathrm{m}^{3}$ at both residential areas (Table 1). BIE also showed a slightly higher standard deviation of 6.98 that reflected scattered readings. The average concentration of $\mathrm{CO}$ of $2.489 \mathrm{ppm}$ at BIE was the highest compared to the other sampling stations, although this value was still low compared to the RMAQG of $35 \mathrm{ppm}$ and the New Malaysia Ambient Air Quality Standard (2020) of $30 \mathrm{ppm}$. No $\mathrm{SO}_{2}$ concentrations were detected at the residential areas (S9 and $\mathrm{CA}) . \mathrm{SO}_{2}$ average of $0.098 \mathrm{ppm}$ was recorded at SIP, in contrast to an average of $0.263 \mathrm{ppm}$ at with a maximum value of $0.7 \mathrm{ppm}$ at BIE. The results at BIE surpassed all readings for $\mathrm{PM}_{10}$, $\mathrm{CO}, \mathrm{SO}_{2}$, and $\mathrm{NO}_{2}$ than at the other stations. The air quality at the residential areas was relatively better than the industrial areas.

Table 1. Comparison of $\mathrm{PM}_{10}, \mathrm{CO}, \mathrm{SO}_{2}$, and $\mathrm{NO}_{2}$ concentrations

\begin{tabular}{llrrrr}
\hline Parameter & Statistics & \multicolumn{1}{c}{ BIE } & \multicolumn{1}{c}{ SIP } & \multicolumn{1}{c}{ S9 } & \multicolumn{1}{c}{ CA } \\
\hline $\mathrm{PM}_{10}$ & Mean & 21.355 & 10.874 & 8.192 & 8.203 \\
& Standard Deviation & 6.958 & 2.079 & 1.730 & 2.149 \\
& Minimum & 10.200 & 5.300 & 4.200 & 2.700 \\
& Maximum & 32.400 & 15.200 & 11.400 & 15.400 \\
\hline \multirow{4}{*}{$\mathrm{CO}$} & Mean & 2.492 & 0.606 & UD & UD \\
& Standard Deviation & 1.412 & 0.560 & UD & UD \\
& Minimum & UD & UD & UD & UD \\
& Maximum & 7.500 & 1.600 & UD & UD \\
\hline \multirow{3}{*}{$\mathrm{SO}_{2}$} & Mean & 0.263 & 0.100 & UD & UD \\
& Standard Deviation & 0.154 & 0.061 & UD & UD \\
& Minimum & 0.100 & UD & UD & UD \\
& Maximum & 0.700 & 0.300 & UD & UD \\
\hline \multirow{3}{*}{$\mathrm{NO}_{2}$} & Mean & 0.329 & 0.253 & 0.152 & 0.167 \\
& Standard Deviation & 0.073 & 0.055 & 0.052 & 0.069 \\
& Minimum & 0.200 & 0.100 & 0.100 & 0.100 \\
& Maximum & 0.520 & 0.400 & 0.350 & 0.350 \\
\hline
\end{tabular}

Legend: UD represents undetected values

The ANOVA analysis tested significant differences for all parameters of air pollutants consisting of $\mathrm{PM}_{10}, \mathrm{CO}, \mathrm{SO}_{2}$, and $\mathrm{NO}_{2}$ between the averages at the four sampling stations. Tukey's Honest Significant Difference (Tukey HSD) test was used to determine which station pairs showed significant differences between one another (Table 2). Comparison between the industrial areas such as SIP and the other stations, as well as between BIE and the other stations differed significantly at the time when the air sampling were taken indicating the differences between the air quality between the industrial areas and the residential areas. Several reasons that can cause the readings in the residential areas to be lower than the industrial areas such as from the movement of pollutants through transportation, dispersion, and deposition. The wind flows and turbulence produced by the interaction of the local wind with complex structures such as buildings can cause pollutants to dilute at higher wind speeds, and also mixing pollutants vertically during unstable thermal conditions (Watson et al., 1988). Yuval et al., (2020) 
confirmed from their study that atmospheric stability and turbulence override the impact of local pollution sources and meteorological conditions explains the relatively low concentrations in their study area.

Table 2. Tukey HSD Multiple Comparisons for air parameters

\begin{tabular}{|c|c|c|c|c|c|}
\hline (I) Station & $\begin{array}{c}\text { (A) } \\
\text { Station }\end{array}$ & $\begin{array}{c}\text { Average } \\
\text { Difference } \mathrm{PM}_{10}\end{array}$ & $\begin{array}{c}\text { Average } \\
\text { Difference CO }\end{array}$ & $\begin{array}{c}\text { Average } \\
\text { Difference } \mathrm{SO}_{2}\end{array}$ & $\begin{array}{c}\text { Average } \\
\text { Difference } \mathrm{NO}_{2}\end{array}$ \\
\hline \multirow[t]{3}{*}{ SIP } & S9 & $2.688 *$ & $.588 *$ & $.099 *$ & $.992 *$ \\
\hline & $\mathrm{CA}$ & $2.675 *$ & $.588^{*}$ & $.099 *$ & $.859 *$ \\
\hline & BIE & -10.465 & -1.902 & -0.165 & -0.763 \\
\hline \multirow[t]{3}{*}{ S9 } & SIP & -2.688 & -0.588 & $-.0985 *$ & -0.992 \\
\hline & $\mathrm{CA}$ & -0.0123 & 0 & 0 & -0.134 \\
\hline & BIE & -13.152 & -2.489 & -0.263 & -1.755 \\
\hline \multirow[t]{3}{*}{ CA } & SIP & -2.675 & -0.588 & -0.099 & -0.859 \\
\hline & S9 & 0.012 & 0 & 0 & 0.134 \\
\hline & BIE & -13.14 & -2.489 & -0.263 & -1.622 \\
\hline \multirow[t]{3}{*}{ BIE } & SIP & $10.465 *$ & $1.902 *$ & $.165 *$ & $.763 *$ \\
\hline & S9 & 13.152 & $2.489 *$ & $.263 *$ & $1.755 *$ \\
\hline & $\mathrm{CA}$ & $13.140 *$ & $2.489 *$ & $.263 *$ & $1.622 *$ \\
\hline
\end{tabular}

Legend: * represents the average difference at significant level of 0.05

The forward trajectory analysis showed slightly different patterns of low level air flow during the 5 days. On the $1^{\text {st }}$ and $2^{\text {nd }}$ June, the air particles advected to the north and northeast direction from BBB. Due to the weak wind regime, the distance travelled by the air particles were limited to about $40 \mathrm{~km}$ only. The forward trajectory on $3^{\text {rd }}$ June showed a forward northerly then southerly path after about 12 hours, while the forward trajectories on the $4^{\text {th }}$ and $5^{\text {th }}$ June 2011 were in a southerly direction for approximately 11 hours and then backed in a northeast direction hereafter. The distance travelled by the air particles was longer for approximately $400 \mathrm{~km}$ due to the deep and stronger southwesterly wind regime (Figure 4).

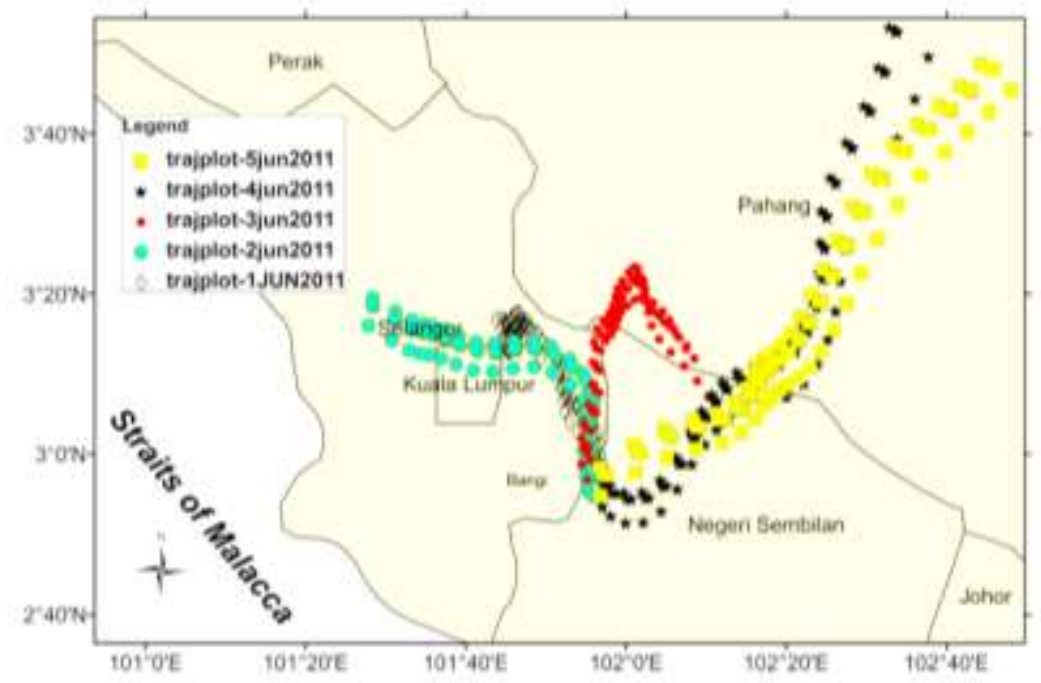

Figure 4. The forward air trajectories of particles leaving Bangi from 1 June to 5 June 2011. 
A simulation from the Hysplit4 model on dispersion of $\mathrm{PM}_{10}$ concentrations based on default values over the top model a height of $10 \mathrm{~km}$ from the two industrial areas was performed for a duration of 48 hours on each day from 1 to 5 June 2011 (Figure 5). Slightly different plume patterns were simulated on the different days from the sources depending on the wind regime of the day during the southwest monsoon. The plumes on 1 and 2 June 2011 travelled in a southerly direction, spreading over the west coast of central Peninsular Malaysia towards the Straits of Malacca (Figure 5a and 5b). However, the plume advected in a more southerly direction and northeasterly direction on 3 June (Figure 5c) in contrast a more northeastward direction on 4 June and affected the eastern coast of the peninsula (Figure $5 \mathrm{~d}$ ). The plume was spread over a northward direction on 5 June (Figure 5e).
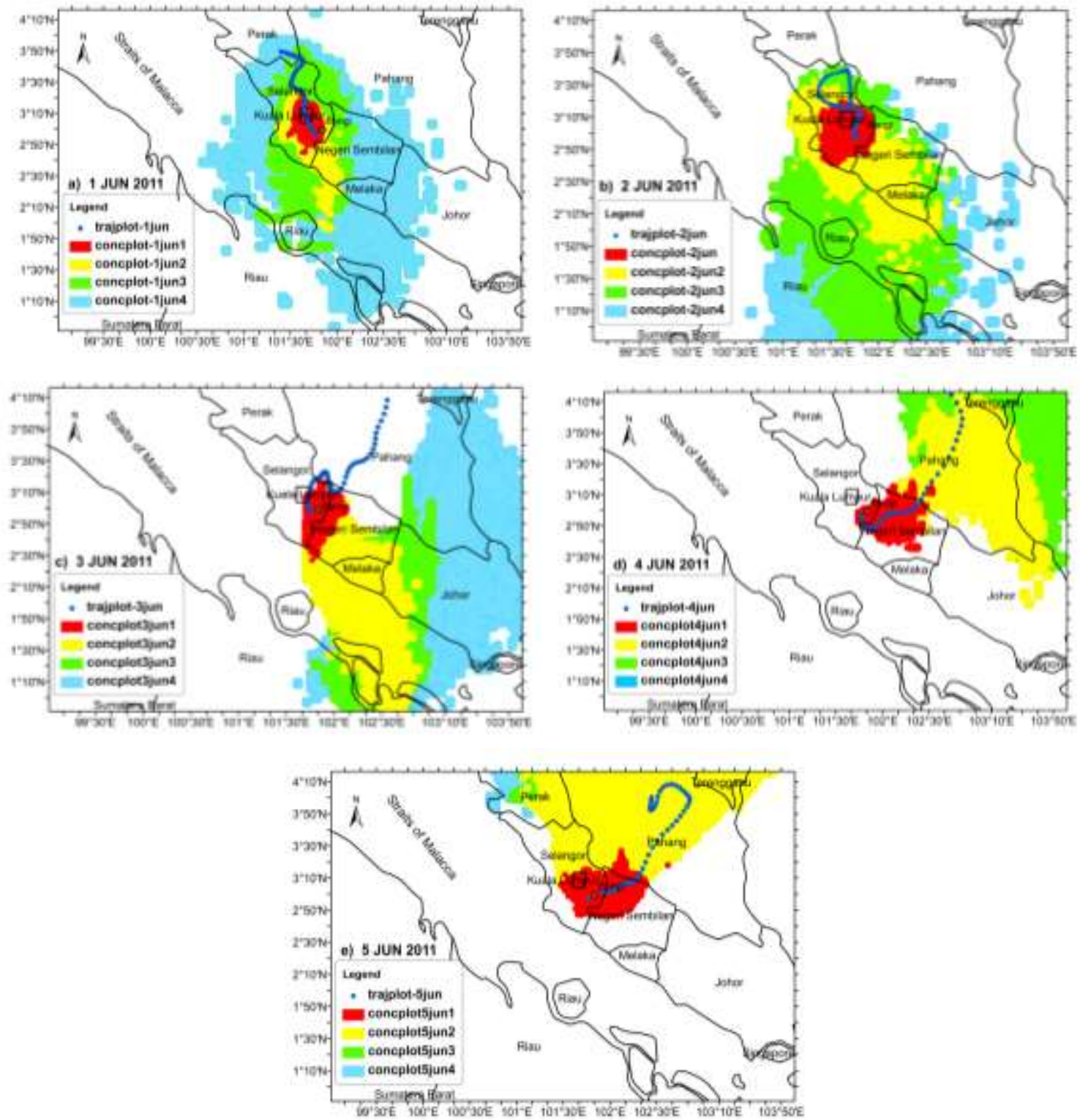

Figure 5. The dispersed plumes of $\mathrm{PM}_{10}$ concentrations $\left(\mu \mathrm{g} / \mathrm{m}^{3}\right)$ from the Bangi industrial sites on (a) $1 \mathrm{June}$, (b) 2 June, (c) 3 June, (d) 4 June and (e) 5 June 2011. Each different shade of colour represents the spread of plume at every 12 hours within a simulation of 48 hours. 
A small survey was conducted to determine the perception of some residents in BBB on the air quality in the housing area of S9. The random sample consisted 53 respondents, of which 38 men $(72 \%)$ and $28 \%$ women were interviewed. Approximately $17 \%$ of respondents were youth under 20 years, while $23 \%$ were between the ages of 31 years to 40 years, with only $8 \%$ over 51 years. $25 \%$ of the respondents worked in the government service while $34 \%$ worked in the private sector and at the industrial estates. Approximately $36 \%$ of the respondents were university educated followed by $11 \%$ who achieved secondary school education.

The survey showed that $73 \%$ of the respondents fall within the category of the lower income bracket of below RM4,000 per month, with only $21 \%$ earned more than RM5,000. A mere $17 \%$ of the residents had resided in the area for more than 10 years and $68 \%$ of the respondents were aware on the issue of air pollution, and would prefer a residence free of air pollution if they had a choice on their abode.

About $64 \%$ of the residents strongly agreed that the industry had a corporate responsibility to the community in controlling the air pollution emitted from their facilities by also providing some social engagement programs to the surrounding community. However, the respondents generally displayed a positive attitude where about $70 \%$ were satisfied with the quality of air in $\mathrm{BBB}$. The residents were willing to participate in efforts of conserving their environment for a more comfortable quality of life against the threat of pollution from the nearby industries. The study implied that the residents may not be aware that the level of pollutants such as $\mathrm{SO}_{2}$ and $\mathrm{NO}_{2}$ were exceeded during the weekdays. It appears that the pollution from the traffic activities may create a worse effect than the stationary sources from the industrial activities. Unfortunately, no traffic studies are conducted for this investigation.

Thus, from this case study, the existence of the two industrial areas located nearby in the town of BBB have an effect on the air quality to the surrounding area. Although the particulate matter level was considered low and does not pose a problem on the air quality, however, the levels of $\mathrm{CO}$ and NOx will need to be monitored and controlled to reduce the effects of the industrial sector on the township whether the sources are from the industry itself or from the transportation sector that exist as a consequence of the industrial areas. However, better technological applications that are eco-friendly can further minimize the environmental degradation and impact on the quality of life for the communities as a result of the industrial activities. The local authority such as the Majlis Perbandaran Kajang (MPKJ) should consider the impacts on the environment from any future township development. The planning and siting of the residential areas should consider the future congestion of traffic density and the population increase within the new residential areas in controlling the air quality of the surrounding environment.

\section{Conclusion}

The case study that was conducted for a period of five days found that overall, the concentrations of air pollutants such as $\mathrm{PM}_{10}, \mathrm{CO}, \mathrm{SO}_{2}$, and $\mathrm{NO}_{2}$ were higher at the industrial areas at BIE and SIP compared to the nearby residential areas. Hourly average $\mathrm{PM}_{10}$ concentrations at the industrial SIP recorded concentrations that ranged from 5 to $15.2 \mu \mathrm{g} / \mathrm{m}^{3}$ while at BIE readings were slightly higher from 10.2 to $32.4 \mu \mathrm{g} / \mathrm{m}^{3}$. The residential areas recorded lower hourly concentrations ranging from $4.2 \mu \mathrm{g} / \mathrm{m}^{3}$ to $11.4 \mu \mathrm{g} / \mathrm{m}^{3}$ at $\mathrm{S} 9$ while readings ranged from $2.7 \mu \mathrm{g} / \mathrm{m}^{3}$ to $15.4 \mu \mathrm{g} / \mathrm{m}^{3}$ at CA. Even when the maximum hourly concentration was converted to the averaging concentration of 24 hour (multiplying by a factor of 0.4107 following 
Duffee et al., (1991), the hourly concentrations, as comparisons, were still below the 24 hour criteria value set by the DOE of $150 \mu \mathrm{g} / \mathrm{m}^{3}$ prior to 2015, or the New Malaysia Ambient Air Quality Standard (2020) criteria of $100 \mu \mathrm{g} / \mathrm{m}^{3}$ and the WHOAQG of $50 \mu \mathrm{g} / \mathrm{m}^{3}$ for an exposure period of 24 hours. The impact of the industrial are to $\mathrm{BBB}$ as a whole and to the residents that have relatively low pollutant concentration, dependent on the state of the wind velocity when the readings were taken for this study.

The CO concentrations were beneath the criteria set by the DOE at the residential areas, but exceeded the maximum level allowed at BIE. The daily average concentrations of $\mathrm{NO}_{2}$ exceeded the criteria set by the New Malaysia Ambient Air Quality Standard (2020) of 0.15 ppm for an exposure period of 1 hour at both industrial areas. The presence of the industrial areas certainly affected the air quality, as was shown by the spatial trajectory distribution and simulated plumes dispersed by the monsoon winds over the western coast of Peninsular Malaysia. The simulated air trajectory and dispersion from the sources located at the two nearby industrial sites showed that local wind velocity plays an important role in dispersing the pollutant from their sources. Southeasterly winds have the effect of dispersing the pollutants towards Kuala Lumpur, while southweasterly winds have the effect of dispersing the pollutants towards the east coast of Peninsular Malaysia.

Thus, the consequences of the existence of the industrial areas on the air quality to the surrounding area are inevitable as shown by this case study. The impact of the industrial to BBB as a whole and to the residents displayed relatively low pollutant concentration for air particles. To overcome the effects of the industrial sector several control techniques have been introduced and monitored by the Department of Environment. However, better technological applications that are eco-friendly can further minimize the environmental degradation and impact on the quality of life for the communities as a result of the industrial activities. The planning of the land use and siting of the residential areas should be considered with the influx of traffic and the density of population within the areas and the projected growth of the township concerned in controlling the air quality of the surrounding environment.

\section{References}

Department of Environment (DOE) (2007). Environmental requirement: A guide for investors. Department of Environment, Ministry of Natural Resources and Environment. Retrieved from: https:/enviro.doe.gov.my, Accessed in December 2015.

Department of Environment (DOE) (2010). Environmental requirements: A guide for investors. Department of Environment, Ministry of Natural Resources and Environment Wisma Sumber Asli, Precinct 4, Federal Government Administrative Centre, Retrieved from http://www.doe.gov.my/eia/wp-content/uploads/2012/03/A-Guide-For-Investors1.pdf

Department of Environment (DOE) (2012). Malaysia Environmental Quality Report 2012. . Retrieved from: https:/enviro.doe.gov.my, Accessed in December 2015.

Department of Statistics Malaysia (2013). Compendium of Environment Statistics, Retrieved from: https://www.statistics.gov.my/dosm. Accessed in December 2015.

Draxler, R., Stunder, B, Rolph, G., Stein, A. \& Taylor, A. (2013). "Hysplit4 user Guide," Retrieved from: http://www.arl.noaa.gov/documents/reports/hysplit user guide.pdf. Accessed in December 2015. 
Duffee, R. A., O'Brien, M. A. \& Ostojic, N. (1991). Odor Modeling - Why and How. Recent Developments and Current Practices in Odor Regulations, Controls and Technology. Pittsburg: Air \& Waste Management Association.

Eck, T. F., Holben, B. N., Giles, D. M., Slutsker, I., Sinyuk, A., Schafer, J. S., Smirnov, A., Sorokin, M., Reid, J. S., Sayer, A. M., Hsu, N. C., Shi, Y. R., Levy, R. C., Lyapustin, A., Rahman, M. A., Liew, S. C., Salinas Cortijo, S. V., Li, T., Kalbermatter, D., Keong, K. L., Muhammad Elifant Yuggotomo, Fanni Aditya, Maznorizan Mohamad, Mastura Mahmud, Tan Kok Chong, Hwee San Lim, Yeap Eng Choon, Gumilang Deranadyan, Sheila D.A. Kusumaningtyas, \& Edvin Aldrian (2019). AERONET remotely sensed measurements and retrievals of biomass burning aerosol optical properties during the 2015 Indonesian burning season. Journal of Geophysical Research: Atmospheres, 124(8), $4722-4740$.

Ghosh, S., Rabha, R., Chowdhury, M., \& Padhy P.K. (2018). Source and chemical species characterization of $\mathrm{PM}_{10}$ and human health risk assessment of semi-urban, urban and industrial areas of West Bengal, India. Chemosphere, 207, 626-636.

Gorham, R. (2002). Air pollution from ground transportation. An assessment of causes, strategies and tactics, and proposed actions for the international community. United Nations Publications. Retrieved from: http://www.un.org/esa/gite/csd/gorham.pdf

Mahmud, M. (2009a). Mesoscale equatorial wind prediction in Southeast Asia during a haze episode of 2005. Geofizika, 26(1), 67-84.

Mahmud, M. (2009b). Simulation of equatorial wind field patterns with TAPM during the 1997 haze episode in Peninsular Malaysia. Singapore Journal of Tropical Geography, 30, 312326.

Mahmud, M (2013). Assessment of atmospheric impacts of biomass open burning in Kalimantan, Borneo during 2004. Atmospheric Environment, 78, 242-249.

Mohd Dlan, N., \& Kasim, R. (2012). Exploratory study for the neighbourhood facilities provision in Bandar Baru Bangi, Malaysia. Proceedings International Conference of Technology Management, Business and Entrepreneurship 2012 (ICTMBE2012), Renaissance Hotel, Melaka, Malaysia 18-19 Dec 2012.

Paraschiva, S. \& Paraschiva, S-M. (2019). Analysis of traffic and industrial source contributions to ambient air pollution with nitrogen dioxide in two urban areas in Romania. Energy Procedia, 157, 1553-1560

Pinyochatchinda, S., \& Walsh, J. (2014). Pollution Management and Industrial Estates: Perceptions of Residents in the Vicinity of Map Ta Phut Industrial Estate, Thailand. Information Management \& Business Review, 6(1), 42-48.

Rolph, G., Stein, A., \& Stunder, B. (2017). Real-time Environmental Applications and Display sYstem: READY. Environmental Modelling \& Software, 95, 210-228.

Sonobe, T., \& Keijiro, O. (2006). Cluster-based industrial development: An East Asian Model. Basingstoke: Palgrave Macmillan. DOI 10.1057/9780230596061

Watson, A.Y., Bates R.R., \& Kennedy, D., (1988). Air Pollution, the Automobile, and Public Health, Washington (DC): National Academies Press

Yuval, I., Tritscher, T., Raz, R., Levi, Y., Levy, L., \& Brodaya, D. M. (2020). Emissions vs. turbulence and atmospheric stability: A study of their relative importance in determining air pollutant concentrations. Science of The Total Environment, 733: Article 139300, In Press 